\title{
BIOLOGINEI IVAIROVEI PALANKIŲ ŪKININKŲ DALYVAVIMO LIETUVOS SAUGOMŲ TERITORIJŲ VALDYME VERTINIMAS
}

\author{
Pranas Mierauskas \\ Mykolo Romerio universiteto Politikos ir vadybos fakulteto \\ Viešojo administravimo instituto Aplinkos valdymo centras \\ Ateities g. 20, LT-08303 Vilnius, Lietuva \\ El. paštas: mierauskas@mruni.eu
}

Pateikta 2014 m. gegužès 8 d., parengta spausdinti 2014 m. spalio 15 d.

doi:10.13165/SMS-14-6-2-12

Anotacija. Straipsnyje yra nagrinèjama žemès ükio veiklomis užsiimančių asmenu galimybe dalyvauti saugomu teritoriju valdyme. Pagrindinis demesys yra skiriamas biologinei ịvairovei palankiais būdais ükininkaujantiems asmenims. Aptariama, kokiu ūkininkavimo būdu asmenys bütų tinkami dalyvauti, kokiomis formomis ükininkai galètu isitraukti i saugomu teritoriju valdymą. Daugelyje ekonomiškai išsivysčiusiu šaliu saugomy teritoriju valdyme dalyvauja j̣vairūs suinteresuotieji asmenys, o dalyje ir ūkininkai ar juos vienijančios organizacijos. Suinteresuotuosius asmenis įtraukti i sprendimu priemima galima ịvairiomis formomis, bet tai priklauso nuo to, kaip saugomos teritorijos yra valdomos. Centralizuotai valdant saugomas teritorijas suinteresuotuju asmenu itraukimas yra ribotas, o decentralizuotai yra platesnis. Lietuvos saugomos teritorijos yra valdomos pakankamai centralizuotai, todèl priimant sprendimus dalyvauja ribotas ratas asmenu. Straipsnyje aptariama, ar biologinei j̣vairovei palankiu büdu ūkininkaujantys asmenys turi siekiu, ar jie būtų pajègūs viena ar kita forma įsitraukti i saugom ų teritoriju valdymą. Nustatyta, kad dalis $\bar{u} k i n i n k u$ norètu i sitraukti $j$ sprendimu priemima, nes tai mažintų nesutarimus ar konfliktus tarp ju ir saugomu teritoriju administracijų.

Socialinių mokslų studijos / Societal Studies

(C) Mykolo Romerio universitetas, 2014

(C) Mykolas Romeris University, 2014
ISSN 2029-2244 (online)

http://www.mruni.eu/lt/mokslo_darbai/SMS/ http://www.mruni.eu/en/mokslo_darbai/SMS/ 
Reikšminiai žodžiai: saugomu teritorijų valdymas, ükininkai, suinteresuotieji asmenys, biologinei įvairovei palankus ükininkavimas, agrarinès aplinkosaugos priemonés.

\section{Ivadas}

Diskutuojama, ar gali palankiai aplinkai ūkininkaujantys asmenys dalyvauti viena ar kitokia forma saugomų teritorijų valdyme. Dalis tokių ūkininkų yra suinteresuoti dalyvauti sprendimų priemime bei įvairiuose dialoguose dèl teritorijų tvarkymo. Suinteresuotieji asmenys skirtingai dalyvauja saugomų teritorijų valdyme. Tai priklauso nuo saugomų teritorijų valdymo formos. Jos skirtingose šalyse yra skirtingos, vienose daugiau centralizuotos, kitose decentralizuotos. Paprastai decentralizuotas valdymas yra labiau ekonomiškai išsivysčiusiose šalyse, o centralizuotas mažiau ekonomiškai išsivysčiusiose ir posovietinio režimo šalyse. Taip pat atskiros šalys skirtingai įtraukia suinteresuotuosius asmenis ị saugomų teritorijų valdymą platesniame kontekste, sprendimų priemimą, teritorijų steigimą ar zonavimą, tvarkymo veiklas (Borrini-Feyerabend ${ }^{1}$; Dearden, Bennett, Johnston ${ }^{2}$; Graham, Amos, Plumpt$\mathrm{re}^{3}$; Mierauskas ${ }^{4}$; Mierauskas, Smalskys $;$; Niedzialkowski, Paavola, Jedrzejewska ${ }^{6}$; Stoll-Kleemann, Welp ${ }^{7}$. Šiame darbe saugomų teritorijų valdymo samprata yra kaip P. Mierausko ir V. Smalskio publikacijoje ${ }^{8}$.

V Pasaulio parkų kongrese (2003) buvo suformuluota nauja saugomų teritorijų valdymo koncepcija, arba vadinamoji „naujoji saugomų teritorijų valdymo paradigma 21 amžiui“", pagal kurią suinteresuotieji asmenys turi turèti daugiau teisių

1 Borrini-Feyerabend, G. 2004. Governance of protected areas, participation and equity. In: Biodiversity Issues for Consideration in the Planning, Establishment and Management of Protected Areas Sites and Networks. Technical Report 15. Montreal: Secretariat of the Convention on Biological Diversity.

2 Dearden, P., Bennett, M., Johnston, J. 2005. Trends in global protected area governance. Environmental Management, 36: 89-100.

3 Graham, J.; Amos, B.; Plumptre, T. 2003. Governance Principles for Protected Areas in the 21st Century. Discussion Paper. Ottawa: Institute on Governance in collaboration with Parks Canada and the Canadian International Development Agency.

4 Mierauskas, P. 2012b. Saugomu teritoriju politika ir valdymas. Vilnius: Mykolo Romerio universitetas.

5 Mierauskas, P.; Smalskys, V. 2013. Saugomų teritorijų sistemų organizavimo principai viešojo valdymo kontekste. Viešoji politika ir administravimas, 12 (2): 236-247.

6 Niedzialkowski, K.; Paavola, J.; Jedrzejewska, B. 2012. Participation and protected areas governance: the impact of changing influence of local authorities on the conservation of the Bialowieza Primeval forest, Poland. Ecology and Society, 17 (1): 2. http//dx.doi.org/10.575/ES04461-170102.

7 Stoll-Kleemann, S.; Welp, M. 2006. Towards a more effective and democratic natural resources management. In S. Stoll-Kleemann, M. Welp (Eds.). Stakeholder Dialogues in Natural Resources Management: theory and practice. Berlin - Heidelberg: Springer Verlag: 17-39

Mierauskas, P.; Smalskys, V., supra note 5. 
ir galimybių dalyvauti saugomų teritorijų steigime ir įvairiuose valdymo etapuose (Graham, Amos, Plumptre ${ }^{9}$ IUCN ${ }^{10}$; Lockwood, Kothari ${ }^{11}$; Mose, Weixlbaumer ${ }^{12}$; Phillips ${ }^{13}$ ). Naujoji valdymo koncepcija buvo paremta daugelio specialistų nuomonėmis bei kongreso nutarimais. Tačiau buvo ir šios koncepcijos kritikų, kurie motyvavo, kad per didelis suinteresuotųjų asmenų ịtraukimas ị sprendimų priemimą gali neigiamai paveikti saugomų teritorijų steigimo tikslų igyvendinimą (Dearden ir kt. ${ }^{14}$ ), o saugomose teritorijose svarbiausia yra išsaugoti biologinę ịvairovę (McNeely; Lockwood; Chapman ${ }^{15}$ ). Nepaisant prieštaravimų naujajai koncepcijai, pastaraisiais metais naujoji valdymo koncepcija vis labiau yra remiama ir visuotinai pripažįstama, kad saugomos teritorijos negali būti izoliuotos nuo suinteresuotųjų asmenų. T. Hammer $^{16}$ siūlo, kad saugomų teritorijų administracijos galètų tapti regioninio vystymo centrais, kurios atliktų kai kurias savivaldybių funkcijas ir kompleksiškai tvarkytų teritorijas, apimant kelių savivaldybių atskiras teritorijas, esančias saugomose teritorijose.

Vietiniai gyventojai, žemių savininkai ar valdytojai bei įvairios organizacijos naudoja gamtinius ir kitus išteklius, teritorijas, todèl veiklas reglamentuojantys teisès aktai juos vienaip ar kitaip paveikia. Tokiu būdu demokratiškai valdomose valstybèse suinteresuotiesiems asmenims ar net ir visuomenei yra suteikiama galimybe dalyvauti priimant ịvairaus lygmens sprendimus. Daugelis autorių atskiria suinteresuotuosius asmenis ir visuomenę, jų nesutapatina, tačiau dalis motyvuotą visuomenès dalị priskiria suinteresuotiesiems asmenis. Apibendrinus įvairių autorių pozicijas, suinteresuotuosius asmenis galima apibrèžti kaip institucijas, organizacijas, ìmones, nevyriausybines organizacijas, socialiai organizuotas grupes, bendruomenes, net pavienius motyvuotus asmenis, turinčius bendrą konkrečios veiklos ir jos padarinių inte-

9 Graham, J.; Amos, B.; Plumptre, T., supra note 1.

10 International Union for Conservation of Nature (IUCN). 2003. Recommendations, Vth IUCN World Parks Congress, Durban, South Africa, 8 - 17 September 2003. [http://cmsdata.iucn.org/ downloads/recommendationen.pdf, žiūrèta 2014-02-15].

11 Lockwood, M.; Kothari, A. 2006. Social context. In: Lokwood M., Worboys G.L., Kothari, A. (Eds.). Managing Protected Areas: a global guide. London: Earthscan: 41-72.

12 Mose, I; Weixlbaumer, N. 2007. A new paradigm for protected areas in Europe? In Mose I. (Ed.). Protected Areas and Regional Development in Europe: towards a new model for the 21st century. Aldershot: Ashgate Pub. Ltd., p. 3-19.

13 Phillips, A. 2003. Turning ideas on their head: the new paradigm for protected areas. In Jaireth H., Smyth D. (Eds.). Innovative Governance: Indigenous Peoples, Local Communities and Protected Areas. New Delhi: Ane Books: 45-65.

14 Dearden, P., Bennett, M., Johnston, J. 2005. Trends in global protected area governance. Environmental Management, 36: 89-100.

15 McNeely, J.A.; Lockwood, M.; Chapman, J. 2006. Building Support for Protected Areas. In: M. Lockwood, G. Worboys, A. Kothari (Eds.). Managing Protected Areas. London: Earthscan: 656-676.

16 Hammer, T. 2007. Protected areas and regional development: conflicts and opportunities. In: Mose I. (Ed.). Protected Areas and Regional Development in Europe: towards a new model for the 21st century. Aldershot: Ashgate Pub.ltd.: 21-36. 
resa ar kuriu interesus veiklos gali paveikti (Mierauskas ${ }^{17}$ ). Ittraukus ịvairius suinteresuotuosius asmenis ị sprendimų priemimą galima išvengti konfliktų, o tai palankiai veikia saugomų teritorijų tikslų igyvendinimą, skatina bendradarbiavimą, užtikrina tvarkymo ilgaamžiškumą ir apsaugos tikslų suvokimą. Iš kitos pusės, suinteresuotųjų asmenų įtraukimas ị sprendimų prièmimą neturi ilgametès patirties. Be to, jų tikslai gali būti priešiški, todèl yra būtina juos identifikuoti ir ịvertinti, nustatant jų tikslus, kokiems (privatiems, viešiems, verslo, valstybès ar kt.) interesams atstovauja bei kokiems veiklų sektoriams priklauso (Beierle $e^{18}$; Borrini-Feyerabend ir kt. ${ }^{19}$; Idle, Bines ${ }^{20}$; Loocwood, Kothari ${ }^{21}$; Mierauskas ${ }^{22}$; Oels ${ }^{23}$; Stoll-Kleemann, Welp ${ }^{24}$; Welp ir kt. ${ }^{25}$ ).

Žemès ūkio sektorius turi didelį poveikị saugomų teritorijų apsaugai ir tvarkymui, ypač intensyvaus ūkininkavimo regionuose. Dèl to jose yra gana daug apribojimų žemès ūkio veikloms, bet jų dydis priklauso nuo atskirų saugomų teritorijų kategorijų bei atskirų šalių teisės aktų, reglamentuojančių jose veiklas. Žemių savininkai ir naudotojai susivieniję $\mathfrak{i}$ asociacijas ir kitas visuomenines organizacijas siekia dalyvauti ne tik saugomų teritorijų tvarkyme, bet ir valdyme priimant ịvairius sprendimus (Burchett, Burchett ${ }^{26}$; Mattison, Norris ${ }^{27}$; Mierauskas ${ }^{28}$ ). Daugumos ekonomiškai išsivysčiusių šalių ūkininkų organizacijos daro ịtaką dèl aplinkosauginių apribojimų mažinimo bei saugomų teritorijų valdymui. Siekiant išvengti konfliktų jos kaip suinteresuotieji asmenys yra ịtraukiamos bent ị dalinị saugomų teritorijų valdymą. Lietuvoje ūkininkų organizacijos menkai dalyvauja saugomų teritorijų valdyme, daugiausiai pavieniai ūkininkai ịsitraukia ị saugomų teritorijų tvarkymą. Tai yra dèl kelių

17 Mierauskas, P. 2012b. Saugomu teritoriju politika ir valdymas. Vilnius: Mykolo Romerio universitetas.

18 Beierle, T.C. 2002. The quality of stakeholder - based decisions. Risk Analysis 22: 739-749.

19 Borrini-Feyerabend, G.; Pimbert, M.; Farvar, M. T.; Kothari, A.; Renard, Y. 2007. Sharing Power: a global guide to collaborative management of natural resources. London: Earthscan.

20 Idle, E. T.; Bines, T. J. 2005. Management Planning for Protected Areas. Peterborough: English Nature/Darwin Program initiative.

21 Lockwood, M.; Kothari, A., supra note 11.

22 Mierauskas, P. 2010. Suinteresuotų asmenų dalyvavimas Lietuvos saugomų teritorijų valdyme. Socialiniu mokslu studijos, 3(7): 125-143.

23 Oels, A. 2006. Evaluating stakeholder dialogues. In S. Stoll-Kleemann, M.Welp (Eds.). Stakeholder Dialogues in Natural Resources Management: theory and practice. Berlin Heidelberg: Springer Verlag: 118-151.

24 Stoll-Kleemann, S.; Welp, M., supra note 7.

25 Welp, M.; de la Vega-Leinert, A. C.; Stoll-Kleemann, S.; Jaeger, C. C. 2006. Science - based stakeholder dialogues: theories and tools. Global Environmental Change, 16: 170-181.

26 Burchett, St.; Burchett, S. 2010. Introducing to Wildlife Conservation in Farming. WilleyBlackwell Publ.

27 Mattison, E.H.; Norris, K. 2005. Bridging the gaps between agricultural policy, land-use and biodiversity. Trends in Ecology and Evolution. 20(11): 610-616.

28 Mierauskas, P. 2012a. Gamtosaugos programų igyvendinimo žemès ūkyje socialiniai ekonominiai aspektai. Socialiniu mokslu studijos, 4 (4): 1503-1517. 
priežasčių. Pirma, Lietuvos saugomų teritorijų valdymas yra centralizuotas ir suinteresuotųjų asmenų dalyvavimas jungtinèse tarybose yra gana ribotas (Mierauskas ${ }^{29}$; Mierauskas, Smalskys ${ }^{30}$ ). Antra, ūkininkų organizacijos nèra pakankamai aktyvios, kad siektų dalyvauti priimant spendimus. Tiek Aplinkos ministerijos, tiek Valstybinès saugomų teritorijų tarnybos sprendimai dažnai yra priimami nesikonsultuojant ar nedalyvaujant suinteresuotiesiems asmenims. Nors ūkininkų organizacijos nèra pakankamai aktyvios, tikslinga rinkti ir analizuoti bei vertinti žemės naudotojų, ypač aplinkai palankių ūkininkų, nuostatas ir požiūrius ị žemès naudojimo apribojimus bei galimybes aktyviau įsitraukti ị sprendimų priemimą saugomose teritorijose, nes toks dalyvavimas mažintų konfliktus ir padètų igyvendinti saugomų teritorijų tikslus. Svarbiausias demesys turètų būti nukreiptas ne tik $\mathfrak{i}$ agrarinès aplinkosaugos priemonėse dalyvaujančius ūkininkus, bet ị potencialius biologinei ịvairovei palankiai ūkininkaujančiuosius.

Straipsnio tikslas yra išanalizuoti biologinei ịvairovei palankiai ūkininkaujančių Lietuvos ūkininkų galimybes ir pajègumus dalyvauti saugomų teritorijų valdyme. Siekiant iškelto tikslo buvo sprendžiami šie uždaviniai: apžvelgti biologinei ịvairovei palankiais būdais ūkininkaujančių asmenų dalyvavimo patirtị priimant ịvairius sprendimus kitose šalyse; aptarti motyvaciją ir galimybes ūkininkauti biologinei įvairovei palankiais būdais; išsiaiškinti biologinei ịvairovei palankiai ūkininkaujančių asmenu galimybes ir perspektyvas dalyvauti priimant sprendimus; ịvertinti biologinei ịvairovei palankiai ūkininkaujančių asmenų siekius, kokiomis formomis jie galètų dalyvauti saugomų teritorijų valdyme. Tyrimo objektas yra biologinei įvairovei palankiai ūkininkaujančių ūkininkų siekių ir galimybių dalyvauti saugomų teritorijų valdyme vertinimas. Taikyti šie tyrimo metodai: mokslinès literatūros sistemine ir lyginamoji analizé, anketavimas, duomenų analizé, apibendrinimas, kritinis vertinimas.

\section{Motyvuoti biologinę ịvairovę išsaugoti ūkininkai - potenciali parama igyvendinant saugomų teritorijų tikslus}

Lietuvoje žemès ūkio veiklų poveikis biologinès ịvairovès išsaugojimui yra pakankamai žymus. Aplinkai draugiškas ūkininkavimas bei agrarinių aplinkosaugos priemonių vykdymas mažina neigiamą poveikị aplinkai. Išsivysčiusiose šalyse besivystantis biologinei ịvairovei palankus ūkininkavimas yra nukreiptas išsaugoti bioivvairovę. Tai yra ypač aktualu saugomose teritorijose.

Pažymètina, kad yra skirtumas tarp agrarinèse aplinkosaugos priemonèse dalyvaujančiųjų ir biologinei ịvairovei palankiai ūkininkaujančiųjų. Tradicinėmis agrarinèmis aplinkosauginèmis priemonėmis yra siekiama kuo daugiau įtraukti dalyvių ir apimti didesnius žemés ūkio teritorijų plotus, siekti kiekybinių rezultatų, tačiau

30 Mierauskas, P.; Smalskys, V., supra note 5. 
kokybiniai rezultatai ir pasiekimai nèra vertinami. Tuo tarpu bioịvairovei palankus ūkininkavimas siekia rūšių ir buveinių išsaugojimo kokybinių rezultatų ir pasiekimų (Burton, Schwarz ${ }^{31}$; De Sainte Marie ${ }^{32}$; Höft, Müller, Gerowitt ${ }^{33}$; Mierauskas ${ }^{34}$ ). Toks ūkininkavimas efektyviau prisideda prie Biologinès ịvairovès konvencijos bei kitų tarptautinių susitarimų, Natūralių buveinių ir laukinès augalijos bei gyvūnijos apsaugos $^{35}$, Laukinių paukščių apsaugos ${ }^{36}$ direktyvų igyvendinimo. Už savanorišką sutikimą ūkininkauti bioịvairovei palankiu būdu yra mokamos papildomos kompensacinès išmokos kaip priedas prie agrarinių aplinkosauginių kompensacinių išmokų arba kitais būdais skatinami (Burchett, Burchett ${ }^{37}$; Osbeck ir kt. ${ }^{38}$; Siebert et al ${ }^{39}$; Sherr S., McNeely J. ${ }^{40}$ ). Tačiau ūkininkų motyvacija savanoriškai įsitraukti ị tokias programas nėra didele net ekonomiškai išsivysčiusiose šalyse (Banack $S$., Hvenegaad G. ${ }^{41}$; Burton, Schwarz ${ }^{42}$; De Snoo G. ir kt. ${ }^{43}$; ELN-FAB ${ }^{44}$; Farrington, J. ${ }^{45}$; Fucks, S.;

31 Burton, R., and Schwarz, G. 2013. Result-orientated agri-environment schemes in Europe and their potential for promoting behavioural change. Land Use Policy, 30: 628-641.

32 De Sainte Marie, S. 2013. Rethinking agri - environmental schemes. A result-oriented approach to the management of species-rich grasslands in France. Journal of Environmental Planning and Management, DOI:10.1080/09640568.2013.763772. (http://www.tandfonline.com/doi/ab s/10.1080/09640568.2013.763772\#preview ).

33 Höft, A.; Müller, J.; Gerowitt, B. 2010. Vegetation indicators for grazing activities on grassland to be implemented in outcome-oriented agri-environmental payment schemes in North-East Germany. Ecological Indicators, 10: 719-726.

34 Mierauskas, P. 2011. Biologinei ịvairovei palankaus ūkininkavimo kai kurie socialiniai ekonominiai aspektai. Darnaus vystymosi strategija ir praktika, 1(5): 104-113.

35 Tarybos Direktyva 92/43/EEB $1992 \mathrm{~m}$. gegužès $21 \mathrm{~d}$. dẻl natūralių buveinių ir laukinès faunos bei floros apsaugos. 1992, OL L 206, 7.

36 Tarybos Direktyvą 79/409/EEB 1979 m. balandžio 2 d. dèl laukinių paukščių apsaugos. 1979, OL L 103, 4, 25.

37 Burchett, St.; Burchett, S., supra note 26.

38 Osbeck, M.; Schwarz, G.; Morkvènas, Ž. 2013. Dialogue on ecosystem services, payments and outcome based approaches. Stockholm Environmental Institute

39 Siebert, R.; Toogood, M.; Knierim, A. 2006. Factors affecting European farmers' participation in biodiversity policies. Sociologia Ruralis, 46: 318-340.

40 Sherr, S.; McNeely, J. 2008. Biodiversity conservation and agricultural sustainability: towards a new paradigm of „ecoagriculture“ landscapes. Philosophical Transactions of The Royal Society, B, 363: 477-494.

41 Banack, S.; Hvenegaard, G. 2010. Motivation of landowners to engage in Biodiversity - friendly farming practices in Alberta's Central Parkland region. Human Dimensions of Wildlife, 15: 67-69.

42 Burton, R., and Schwarz, G., supra note 31.

43 De Snoo, G.; Herzon, I.; Staats, H.; Burton, R.; Schindler, S.; van Dijk, J.; Lokhors, A. M.; Bullock, J. M.; Lobley, M.; Wrbka, T.; Schwarz, G.; Musters, C. J. M. 2012. Toward effective nature conservation on farmland: making farmers matter. Conservation Letters, 1: 1-7.

44 ELN-FAB. 2012. Functional agrobiodiversity: Nature serving Europe's farmers. - Tilburg, the Netherlands: ECNC-European Centre for Nature Conservation.

45 Farrington, J. 1998. Organizational roles in farmer participatory research and extension: lessons from the last decade. Natural Resources Perspectives 27: 1 - 4. 
Stein-Bachinger, K. ${ }^{46}$; Goslinga, Williams ${ }^{47}$; Herzon, Mikk ${ }^{48}$; Lokhorst ir kt. ${ }^{49}$ ), juolab Lietuvoje (Mierauskas, 2012b; 2011). Nors šiuo metu Lietuvoje ūkininkų ịsitraukimas ị savanoriškas papildomas gamtosaugos priemones yra nežymus, yra tikslinga ieškoti to priežasčių ir juos skatinti. Paprastai tokias ūkininkavimo formas remia ịvairūs tarptautiniai projektai, tačiau valstybiniu mastu nèra paramos.

Ūkininkų motyvacija ūkininkauti biộvairovei palankiu būdu yra aktuali visoje Lietuvos teritorijoje, bet labiausiai reikia motyvuoti ūkininkus tokiam ūkininkavimui saugomose teritorijose, nes toks ūkininkavimas prisidètų prie saugomų teritorijų tikslų igyvendinimo. Dèl to aktualiausia yra išsiaiškinti to priežastis saugomose teritorijose. Ar taip per dideli dabartiniai ūkininkavimo apribojimai ir papildomi reikalavimai biǫ̣vairovei išsaugoti dar apsunkins žemės ūkio veiklas, ar siūlomos papildomos kompensacinès išmokos yra per mažos, ar nèra pakankamo supratimo apie bioịvairovès išsaugojimo svarbą?

Pastaraisiais metais vis daugiau gamtosaugininkų supranta, kad gamtosaugai motyvuoti ūkininkai, kaip ir miškų žemès naudotojai, gali būti parama ịgyvendinant saugomų teritorijų tikslus. Itvairiose šalyse įtraukimas dalyvauti menką motyvaciją turinčius ūkininkus savanoriškose papildomose gamtosaugos programose yra ịvairiai remiamas ir skirtingai motyvuojami ūkininkai. Yra ne vienas motyvavimo būdų, bet vienas iš populiariausių yra ūkininkų ịtraukimas ị mokymus, kurių metu yra skiriama daug dèmesio biǫ̣vairovei palankiam ūkininkavimui. Kaip parodè ịvairių šalių praktika, dalis iš mokymuose dalyvavusių ūkininkų sutinka dalyvauti papildomose nei agrarinès aplinkosaugos programose. Kita praktika yra ūkio valdų tvarkymo planų rengimo finansavimas, nes daugelyje šalių norint gauti papildomas išmokas būtina parengti tokius planus. Taip remiami ūkininkai dažnai sutinka, kad plane būtų numatytos ir bioịvairovei išsaugoti priemonès. Taip pat dalis ūkininkų sutinka taip ùkininkauti vien dèl finansinès paramos. Žinoma, yra ir kitų skatinimo būdų (Atari ir kt. ${ }^{50}$;

46 Fucks, S.; Stein-Bachinger, K. 2008. Nature Conservation in Organic Agriculture - a manual for arable organic farming in North- east Germany. Bonn: Federal Germany Nature Conservation Agency.

47 Goslinga, E.; Williams, K. J. H. 2010. Connectedness to nature, place attachment and conservation behaviour: testing connectedness theory among farmers. Journal of Environmental Psychology, 30(3): 298-304.

48 Herson, I.; Mikk, M. 2007. Farmers' perception of biodiversity and their willingness to enhance it through agri - environment schemes: a comparative study from Estonia and Finland. Journal for Nature Conservation, 15: 10-25.

49 Lokhorst, A.M.; Staats, H.; van Dijk, J.; van Dijk, E.; de Snoo, G.R. 2011. What's in it for me? Motivational differences between farmers' voluntary and non-subsidized conservation practices. Applied Psychology - International Review, 60(3): 337-353.

50 Atari, D.; Yiridoe, E.; Smale, S.; Duinker, P. 2009. What motivates farmers to participate in the Nova Scotia environmental farm plan program? Evidence and environmental policy implications. Journal of Environmental Management, 90: 1269-1279. 
ELN-FAB ${ }^{51}$; Hodge ${ }^{52}$; Morris, Mills, Crawford ${ }^{53}$; Peerlings, Polman ${ }^{54}$; Schwarz, Morkvènas $^{55}$; Siebert et al. ${ }^{56}$; Toogood, Gilbert, Rientjes ${ }^{57}$ ).

Su sutinkančiais ūkininkauti bioịvairovei palankiais būdais yra sudaromos savanoriškos sutartys, kur yra numatytos papildomos kompensacinès išmokos už gautus kokybinius rezultatus ir pasiekimus. Be to, ùkininkai turi dalyvauti ir agrarinėse aplinkosaugos priemonèse. Žinoma, kad svarbiausia yra papildomos kompensacinès išmokos, nes bioịvairovei palankus ūkininkavimas reikalauja daugiau tiek finansinių, tiek žmogiškụjų bei laiko ir kitų išteklių. Taip pat daugiau išteklių yra reikalinga ir institucijoms, kurios rengia mokymus, atlieka žemès ūkio valdų priežiūrą ir tikrina gautus kokybinius rezultatus ir pasiekimus. Tačiau pripažistama, kad motyvacijos skatinimas yra svarbus veiksnys. Reikia pažymėti, kad dažnai yra sunku ūkininkus ar kitus žemių valdytojus motyvuoti dalyvauti ne tik bioịvairovès išsaugojimo programose, bet ir kitose papildomose savanoriškose programose ar priemonèse (Barnes ir kt. ${ }^{58}$; Rosenberg, Margerum ${ }^{59}$ ). Ypatingai sunku motyvuoti tose saugomose teritorijose, kur yra dideli apribojimai žemès ùkio veikloms. Tai galima pasakyti ir apie Lietuvos saugomas teritorijas.

Suprantama, kad intensyviai ūkininkaujantys asmenys ar organizacijos yra netinkami suinteresuotieji asmenys, galintys prisidèti prie saugomų teritorijų tikslų igyvendinimo. Nèra tikslinga juos ịtraukti ị sprendimų priemimą, nes jų siekiai yra skirtingi nei gamtosaugininkų. Nors išsivysčiusiose šalyse yra siekiama turèti platesni suinteresuotųjų asmenų spektrą, tačiau daugelis autorių mano, kad jų skaičius neturi viršyti gamtosaugos tikslų siekiančiu asmenų, nes tokiu atveju sprendimų priẻmimas bus nukreiptas prieš gamtosaugos tikslus (Beedell, J. D. C., Rehman, T. ${ }^{60}$; Idle,

51 Supra note 44.

52 Hodge, I. 2013. Agri - environment policy in an era of lower expenditure: CAP reform and conservation payments. Journal of Environmental Planning and Management, 56 (2): 254-270.

53 Morris, J.; Mills, J.; Crawford, I.M. 2000. Promoting farmer uptake of agri-environment schemes: the Countryside Stewardship Arable Options Scheme. Land Use Policy, 17 (3): 241-254.

54 Peerlings, J.; Polman, N. 2009. Farm choice between agri - environmental contracts in the European Union. Journal of Environmental Planning and Management, 52 (5): 593-612.

55 Schwarz, G.; Morkvènas, Ž. 2013. Review of outcome based agri-environmental payments and guidelines for the practical implementation of a pilot scheme in Lithuania. Thünen Institute, Baltic Environmental Forum.

56 Siebert, R.; Toogood, M.; Knierim, A., supra note 39

57 Toogood, M.; Gilbert, K.; Rientjes, S. 2004. Farmers and Environment. Assessing the Factors that Effect Farmers' Willingness and Ability to Cooperate with Biodiversity Policies. Tilburg: European Centre for Nature Conservation.

58 Barnes, A.P.; Willock, J.; Toma, L.; Hall, C. 2011. Utilizing a farmer typology to understand farmer behaviour towards water quality management: Nitrate Vulnerable Zones in Scotland. Journal of Environmental Planning and Management, 54 (4): 477-494.

59 Rosenberg, S.; Margerum, R. Landowner motivation for watershed restoration: lessons from five watersheds. 2008. Journal of Environmental Planning and Management, 51 (4): 477-496.

60 Beedell, J. D. C.; Rehman, T. 2000. Using social-psychology models to understand farmers' conservation behaviour. Journal of Rural Studies, 16: 117-127. 
Bines $^{61}$; Niedzialkowski, Paavola, Jedrzejewska ${ }^{62}$ ). Dèl to daugelyje išsivysčiusių šalių visų pirma siekiama dialogų su biologinei ịvairovei palankiai ùkininkaujančiais fiziniais ir juridiniais asmenimis, kurie visu pirma gali dalyvauti konsultacijose bei kitose dialogų formose tiek priimant ịvairius sprendimus, tiek aptariant veiklų reglamentavimą, tiek dalyvaujant jungtiniuose valdymo organuose. Tokie asmenys kaip ir kiti suinteresuotieji asmenys yra tinkami dalyvauti jungtiniuose valdymo organuose, nes jie nesiekia paveikti saugomų teritorijų išsaugojimo tikslus.

\section{Biologinei įvairovei palankiai ūkininkaujančių ūkininkų supratimas apie siekius ir galimybes dalyvauti saugomų teritorijų valdyme}

Ūkininkų apklausa vyko dviem etapais. 2010 m. tyrimai atlikti Biržų, Kretingos, Raseinių, Šiaulių, Šilutès, Elektrènų savivaldybių pasirinktose seniūnijose. 2013 m. apklausos atliktos Kèdainių, Molètų, Širvintų, Ukmergès, Utenos, taip pat dar syki pakartotinai paminètose savivaldybèse, tačiau kitose nei ankstesni tyrimai seniūnijose. Abiejuose tyrimuose iš viso dalyvavo 80 ūkininkų. Dalis $2010 \mathrm{~m}$. tyrimo rezultatų buvo pateikti ankstesnèse publikacijose (Mierauskas ${ }^{63}$ ).

Apklausose dalyvavo tie asmenys, kurių žemès ūkis yra pagrindinè veikla ir ju pagrindinės pajamos yra iš šios veiklos. Apklaustųjų ūkininkų 45 proc. sudarè ịvairių kultūrų ariama žeme், 30 proc. šienaujamos ir ganomos pievos, 20 proc. rotuojama žemè (ariama, užsėjama žole ir šienaujama, ganoma, vèl ariama ir taip keičiamas žemès naudojimas) ir 5 proc. kitaip dirbama žemé. Tačiau reikia pažymèti, kad toks procentinis pasiskirstymas pagal žemès ūkio naudmenų rūšis ir vyraujančius pasèlius buvo apklausų metų, nes dalis ūkininkų žemès naudojimo pasiskirstymą pagal žemės ūkio naudmenų rūšis ir vyraujančius pasèlius gali keisti kas keli metai. Bet dalyje regionų pasiskirstymas pagal žemès ūkio naudmenų rūšis išlieka stabilus, pvz., Nemuno žemupio ir Rusnès salos, kur tam tikri pievų plotai negali būti suariami. Tokí procentinị pasiskirstymą pagal žemės ūkio naudmenų rūšis ir vyraujančius pasèlius yra pateikę patys apklaustieji, o matavimų nebuvo atliekama. Visi apklaustieji dalyvauja ar dalyvavo ịvairiose agrarinès aplinkosaugos priemonèse. Nors darbo siekis nebuvo nustatyti dalyvaujančių agrarinėse aplinkosaugos priemonėse motyvaciją, buvo užduotas klausimas, kokie motyvai paskatino dalyvauti ịvairiose priemonėse. Atsakyta buvo taip: 85 proc. dèl to, kad dalyvavimas priemonése yra papildomas léšu šaltinis ir geresnès galimybės siekti kitos Europos Sąungos paramos, noras išsaugoti aplinką 10 proc., 4 proc. geresnis ūkio ịvaizdis ir tik 1 proc. nurodè, kad tai gali būti

61 Idle, E. T.; Bines, T. J., supra note 20.

62 Niedzialkowski, K.; Paavola, J.; Jedrzejewska, B. 2012. Participation and protected areas governance: the impact of changing influence of local authorities on the conservation of the Bialowieza Primeval forest, Poland. Ecology and Society, 17 (1): 2. http//dx.doi.org/10.575/ES04461-170102. 
noras tobulinti ūkininkavimo priemones. Tuo tarpu ịvairiose Vakarų Europos šalyse šie skaičiai skiriasi, išauga noras saugoti aplinką ir siekimas geresnio ūkio įvaizdžio (Siebert et al. ${ }^{64}$; Toogood ir kt. ${ }^{65}$ ).

Šio darbo pagrindinis siekis yra išsiaiškinti ūkininkų norą dalyvauti papildomose biologinei ịvairovei išsaugoti programose ir taip prisidèti prie saugomų teritorijų tikslų iggyvendinimo bei nustatyti, ar jie norètų ir būtų pajègūs dalyvauti ịvairiomis formomis saugomų teritorijų valdyme. Kaip jau buvo konstatuota, ịvairių suinteresuotųjų asmenų dalyvavimas įvairiuose dialoguose ar atskirose valdymo formose mažina konfliktus tarp jų ir saugomų teritorijų administracijų darbuotojų.

Atsižvelgiant ị tai buvo suformuluotos dvi klausimų grupès: pagal ūkininkų norą dalyvauti papildomose programose ir siekius dalyvauti atskirose saugomų teritorijų valdymo formose. Visų pirma buvo pateiktas tradicinis panašiuose tyrimuose naudojamas klausimas „Ar žinote, kas yra biologinè ịvairovè?“. Iš atsakymų matyti, kad didelè dalis turi supratimą apie biologinę ịvairovę, tačiau ne visi tiksliai tai apibūdino (1 pav.). Taip pat mažesnè dalis apklaustųjų tiksliai apibūdino, kas yra biologinei ịvairovei palankus ūkininkavimas. Didesnè dalis tai sieja su agrarinemis aplinkosaugos programomis (2 pav.).

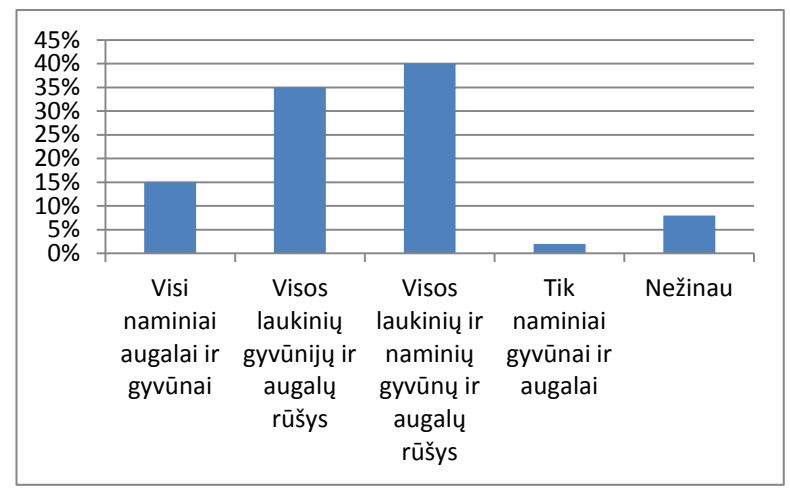

1 pav. Ūkininkų biologinès įvairovès sąvokos supratimas regarding nature conservation set - aside in regions dominated by arable farming. Journal of Nature Conservation, 18: 327-337.

65 Toogood, M.; Gilbert, K.; Rientjes, S. 2004. Farmers and Environment. Assessing the Factors that Effect Farmers' Willingness and Ability to Cooperate with Biodiversity Policies. Tilburg: European Centre for Nature Conservation. 


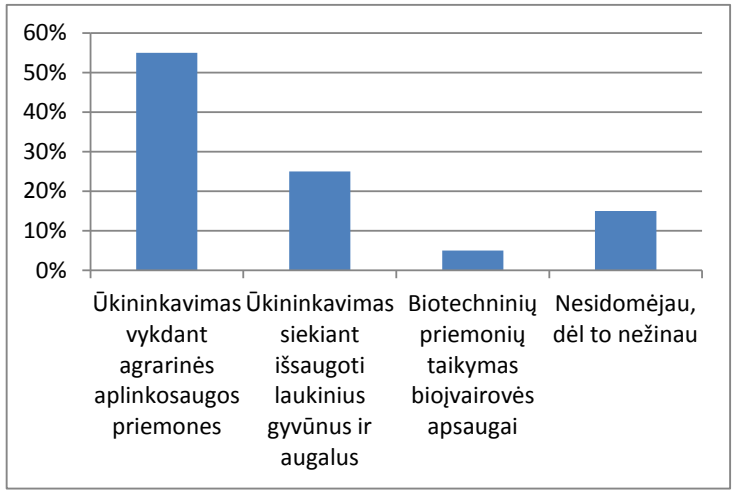

2 pav. Didesnè dalis ūkininkų biologinei ịvairovei palankų ūkininkavimą sieja su agrarinių aplinkosaugos programų vykdymu

Asmenys, teisingai ar panašiai ịvardinę biologiškai palankų ūkininkavimą, aktyviau rinktųsi tokias priemones (65 proc.), tačiau didesnè jų dalis siektų 100 ar 50 proc. didesnių nei agrarinių aplinkosaugos priemonių išmokų (70 proc.). Taip pat ta grupė mano, kad turètų būti išmokų skirtumai igyvendinant saugomose ir nesaugomose teritorijose ir tai yra siejama su didesniais žemès ūkio veiklų apribojimais. Didesnè dauguma teigè, kad saugomose teritorijose yra daug žemės veiklų apribojimų, tačiau dèl apribojimų masto jų nuomonès skyrèsi (3 pav.). Lietuvos saugomose teritorijose ùkinių veiklų apribojimai yra dideli, bet yra skirtingi atskiroms saugomų teritorijų kategorijoms. Kadangi Lietuvos saugomų teritorijų sistema yra paini, tai klausimyne buvo suformuluoti klausimai tik apie tradicinių saugomų teritorijų grupes: nacionaliniai ir regioniniai parkai, draustiniai, ekologinès apsaugos zonos ir pan. Apklaustųų atskirų kategorijų (grupių) supratimas yra skirtingas. 85 proc. kaip atskiras kategorijas (grupes) išskiria nacionalinius ir regioninius parkus, 5 proc. žino, kad draustiniai yra skirstomi $\mathfrak{i}$ atskiras grupes, o 10 proc. visas kategorijas traktuoja kaip saugomas teritorijas. J. Raudonyte் ${ }^{66}$ taip pat teigia, kad sąlygos ūkinei veiklai nèra palankios, tenka riboti atskiras veiklas. Tikètina, kad tai galima sieti su tuo, kokio pobūdžio problemų jie turèjo su saugomų teritorijų administracijų darbuotojais.

66 Raudonyte, J. 2009. Ūkinè veikla Lietuvos valstybiniuose parkuose. Annales Geographicae, 42: 67-76. 


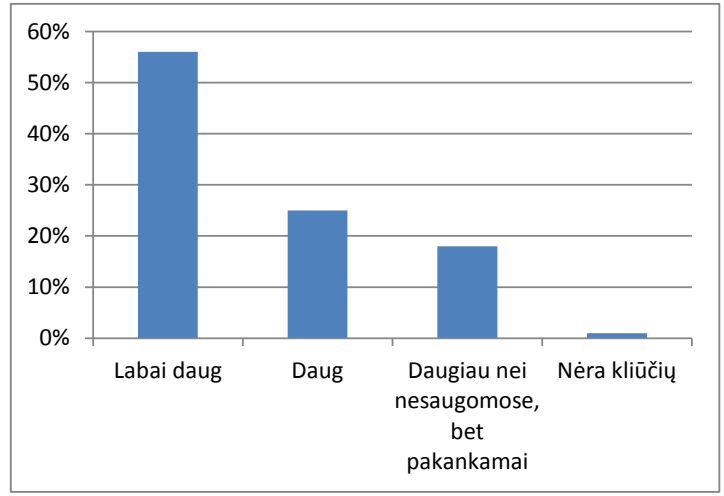

3 pav. Ūkininkai skirtingai ịvertino žemès ūkio veiklų apribojimus saugomose teritorijose

Siekiant nustatyti ūkininkų nuomonę apie dalyvavimą daliniame saugomų teritorijų valdyme buvo klausiama, ar būtų tikslinga pavieniams asmenims ar ūkininkų organizacijomis dalyvauti įvairiose valdymo formose. Didesnè dalis mano, kad tai būtų tikslinga ir geriau išsprendžiamos problemos, mažinama priešprieša tarp ūkine veikla užsiimančių asmenų ir saugomų teritorijų administracijų darbuotojų (4 pav.). Dalinis dalyvavimas valdyme ir priimant sprendimus ūkininkų yra suprantamas skirtingai, bet didesnè dalis mano, kad tai vienokiu ar kitokiu būdu padès optimizuoti ūkinių veiklų apribojimus. Yra keletas būdų, kaip jie galètų dalyvauti (5 pav.). Taip pat norèta išsiaiškinti, koki poveiki galètų padaryti ūkininkų ar jų organizacijų dalyvavimas saugomų teritorijų valdyme (6 pav.). Didesnė dalis mano, kad saugomų teritorijų tikslų igyvendinimui neigiamo poveikio nebūtų, bet tai padètų optimizuoti per didelius keliamus apribojimus ir skatintų palankesnį aplinkai ūkininkavimą.

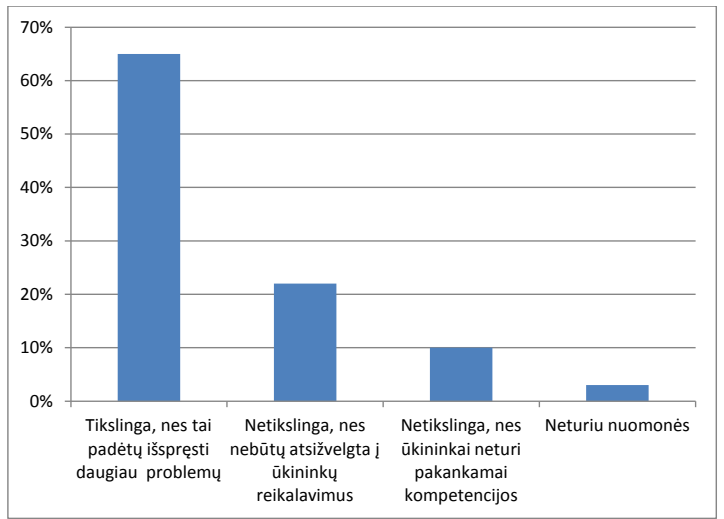

4 pav. Didžiausia dalis ūkininkų mano, kad juos yra tikslinga ịtraukti ị dalinị saugomų teritorijų valdymą, nes tai skatintų spręsti esamas problemas 


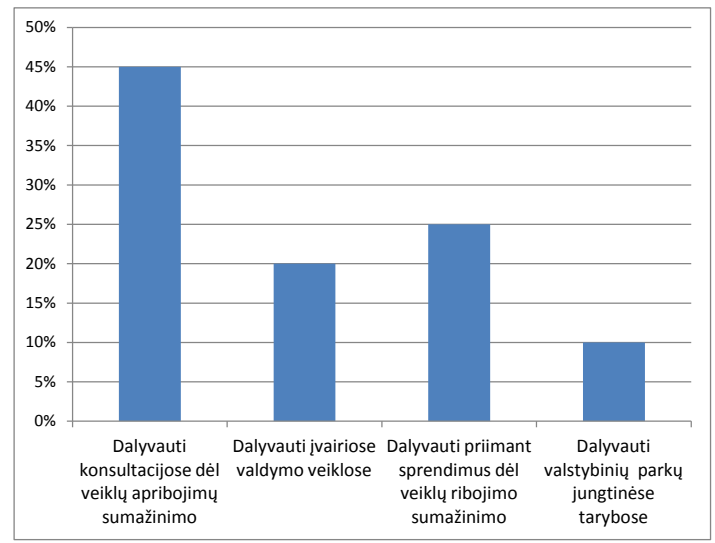

5 pav. Buvo pasiūlyti keli dalyvavimo saugomų teritorijų valdyme būdai

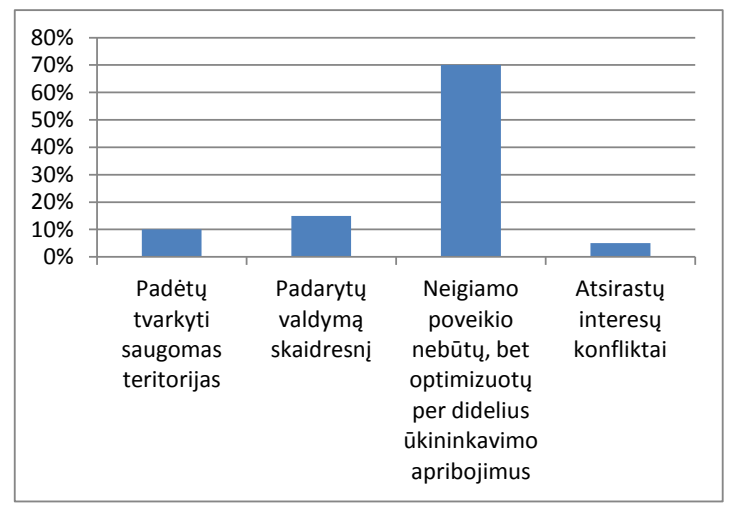

6 pav. Dauguma apklaustųjų mano, kad ūkininkų ar jų organizacijų dalyvavimas nepadarytų neigiamo poveikio saugomų teritorijų tikslų igyvendinimui

Apklausose dalyvavo aplinkai palankiai ūkininkaujantys, dèl to jų nuomonès nuo intensyviai ūkininkaujančių turètų skirtis, nes pastarųjų tikslas yra ekonominė nauda. Kaip parodè apklausos, ganyklų ir pievų daugiau nei ariamos žemès turintys ùkininkai yra labiau linkę i papildomas programas, nukreiptas išsaugoti biologinę ìvairovę (80 proc.). Žinoma, tai gali būti sietina ir su žemès naudojimo ypatumais. Pievose ir ganyklose yra mažiau reikalinga ịdiegti naujų priemonių nei ariamose žemėse. Pirmuoju atveju tai daugiausia sietina su vėlesniu šienavimu, gyvulių tankio ploto vienete (ha) mažinimu, mineralinių trąšų mažinimu ir pan. Tuo tarpu ariamose 
žemėse yra reikalingos naujos priemonės, kaip sklypo pakraštyje palikti neartas juostas (užsodinant medžiais, krūmais ar tik paliekant žolinę augaliją), atvirose plotuose palikti nesuartas juostas, suformuoti mažas giraites ar pasodinti pavienius medžius ir pan. İdiegiant šias biologinès ịvairovès išsaugojimo priemones yra prarandama dalis ariamos žemès ir nèra garantijos, kad papildomos kompensacinès išmokos padengs nuostolius. Tokios pozicijos papildomų priemonių taikymo klausimu laikosi ne tik Lietuvos, bet ir kitų šalių ūkininkai, tačiau selektyviai galima rasti ir sutinkančių dalyvauti. Vokietijoje buvo vykdoma programa dèl papildomų biologinės įvairovès išsaugojimo priemonių įdiegimo ariamose žemèse, ją paverčiant neariama žeme. Pirminị norą dalyvauti programoje išreiškè 85 proc. parinktų žemès naudotojų, tačiau skirtumai buvo tarp didesnius ar mažesnius žemès plotus turinčių, taip pat skirtingo derlingumo žemès turinčių bei ūkininkų, gyvenančių skirtinguose šalies regionuose (Siebert ir kt. ${ }^{67}$ ). Šioje programoje vykdyti mokymai padidino sutinkančių dalyvauti gamtosaugos programose skaičiu.

Atsižvelgiant ị užsienio šalių patirtị bei ši tyrimą, yra tikslingiau siekti, kad biologinei ịvairovei palankiai ūkininkaujantys būtų tinkami ir galètų būti ịtraukiami ị saugomų teritorijų gamtosaugos programas ar dalyvauti vienokiu ar kitokiu būdu įvairiuose dialoguose, derinant saugomų teritorijų tikslus bei ūkininkų poreikius. Dalyvavimas jungtinèse tarybose ar priimant sprendimus būtų tikslingas aktyvioms ūkininkų visuomeninems organizacijoms. Pavieniai ūkininkai tinkami dalyvauti dialoguose su atskirų saugomų administracijų darbuotojais. Ūkininkus, kaip ir kitus suinteresuotuosius asmenis, yra tikslinga ịtraukti ị naujų saugomų teritorijų steigimo procesus. Kaip parodè keli atvejai Lietuvoje bei „Natura 2000“ steigimas Vokietijoje $\left(E b e{ }^{68}\right)$, suinteresuotieji asmenys stabdo naujų saugomų teritorijų steigimą.

\section{Aptarimas}

Ūkininkų motyvacija dalyvauti papildomose gamtosaugos programose nèra didelè dèl kelių priežasčių. Visų pirma tai papildomos išlaidos, kurių Lietuvoje šalies mastu nekompensuoja, papildomi žmogiškieji, laiko ir techniniai ištekliai. Dèl to ūkininkai ịsitraukia ị ịvairias Kaimo plètros programos agrarinès aplinkosaugos priemones, kurios siekia kiekybinių rezultatų. Gamtosaugos programose yra siekiama kokybinių rezultatų ir pasiekimų, dèl to jose dalyvauja tie ūkininkai, kurie yra labiau motyvuoti saugoti biologinę ịvairovę bei gauti papildomas kompensacines išmokas iš îvairių Lietuvoje veikiančių tarptautinių fondų. Biologinei įvairovei palankiai ūkininkaujantys ūkininkai turi ne tik motyvaciją, bet ir daugiau gamtosaugos žinių. Todèl reikia mažiau išteklių jų mokymams ir yra lengviau pasiekiami tikslai. Kaip yra

67 Siebert, R.; Berger, G.; Lorenz, J.; Pfeffer, H., supra note 64.

68 Eben, M. 2006. Public participation during Site Selection for Natura 2000 in Germany: The Bavarian Case. In: S. Stoll - Kleemann, M. Welp (Eds.). Stakeholder Dialogues in Natural Resources Management: theory and practice. Berlin - Heidelberg: Springer Verlag: 261-274. 
nustatyta tyrime, biologinei ịvairovei palankiai ūkininkaujantys ūkininkai yra linkę issitraukti viena ar kita forma ị saugomų teritorijų valdymą. Jo metu buvo nustatyta, kad tokie ūkininkai prisidètų prie saugomų teritorijų tikslų igyvendinimo. Dalyvavimas saugomų teritorijų valdyme yra galimas ne tik atliekant gamtotvarkos priemones ar kitaip tvarkant teritorijas, bet ir dalyvaujant daliniuose sprendimų priemimuose, ypač svarstant ūkininkavimo reglamentavimo klausimus. Dalis ūkininkų yra linkę dalyvauti įvairiuose konsultaciniuose dialoguose ir jungtinèse saugomų teritorijų tarybose. Pagrindinis tokių ūkininkų siekis yra veiklų reglamentavimo sureguliavimas abipusiu susitarimu bei konfliktų tarp saugomų teritorijų administracijų ir žemès naudotojų mažinimu. Sumažinus nesutarimus ir konfliktus būtų efektyviau igyvendinami Lietuvos saugomų teritorijų tikslai.

\section{Išvados}

Tirtų Lietuvos ūkininkų supratimas apie biologinę ịvairovę yra skirtingas, tačiau didesnè dalis turi apie ją žinių, dèl to galètų dalyvauti atskirose papildomose programose. Tarp apklaustujų supratimas apie biologinei ịvairovei palankų ūkininkavimą yra daugiau nei per pus mažesnis ir labiau siejamas su agrarinių aplinkosaugos programų vykdymu. Tai būtų galima sieti su papildomų biologinei ịvairovei išsaugoti palankių priemonių nerèmimu valstybiniu lygmeniu.

Ūkininkų žinios apie atskiras saugomų teritorijų kategorijas ir grupes yra skirtingos, tačiau didesnè jų dalis skiria nacionalinius ir regioninius parkus, draustinius. Didesnè dalis yra ịsitikinę, kad žemės ūkio veiklų reglamentavimas saugomose teritorijose yra per didelis, tačiau nebuvo pateikta reglamentavimo skirtumų pagal atskiras kategorijas ar grupes.

Dauguma respondentų yra ịsitikinę, kad dalinis dalyvavimas saugomų teritorijų valdyme sumažintų per didelius žemès naudojimo apribojimus bei sumažintų esamus konfliktus tarp žemés naudotojų ir saugomų teritorijų administracijų darbuotojų.

Ūkininkai būtų linkę dalyvauti konsultacijose ir dialoguose dèl veiklų ribojimo mažinimo, tačiau tai nedarytų neigiamo poveikio saugomų teritorijų gamtosaugos tikslų igyvendinimui. Konfliktų sumažinimas prisidètų prie tinkamesnio gamtosaugos veiklų igyvendinimo ir skatintų norą labiau įsitraukti ị teritorijų tvarkymą.

\section{Literatūra}

Atari, D.; Yiridoe, E.; Smale, S.; Duinker, P. What motivates farmers to participate in the Nova Scotia environmental farm plan program? Evidence and environmental policy implications. Journal of Environmental Management. 2009, 90: 1269-1279.
Banack, S.; Hvenegaard, G. Motivation of landowners to engage in Biodiversity friendly farming practices in Alberta's Central Parkland region. Human Dimensions of Wildlife. 2010, 15: 6769. 
Barnes, A. P.; Willock, J.; Toma, L.; Hall, C. Utilizing a farmer typology to understand farmer behaviour towards water quality management: Nitrate Vulnerable Zones in Scotland. Journal of Environmental Planning and Management. 2011, 54 (4): 477-494.

Beedell, J. D. C.; Rehman, T. Using socialpsychology models to understand farmers' conservation behaviour. Journal of Rural Studies. 2000, 16: 117-127.

Borrini-Feyerabend, G.; Pimbert, M.; Farvar, M. T.; Kothari, A.; Renard, Y. Sharing Power: a global guide to collaborative management of natural resources. London: Earthscan, 2007.

Borrini-Feyerabend, G. Governance of protected areas, participation and equity. In: Biodiversity Issues for Consideration in the Planning, Establishment and Management of Protected Areas Sites and Networks. Technical Report 15. Montreal: Secretariat of the Convention on Biological Diversity, 2004.

Burchett, St.; Burchett, S. Introducing to Wildlife Conservation in Farming. Willey-Blackwell Publ.

Burton, R.; Schwarz, G. Result-orientated agri-environment schemes in Europe and their potential for promoting behavioural change. Land Use Policy. 2013, 201, 30: 628-641.

Dearden, P.; Bennett, M.; Johnston, J. Trends in global protected area governance. Environmental Management. 2005, 36: 89-100.

De Sainte Marie, S. Rethinking agri - environmental schemes. A result-oriented approach to the management of species-rich grasslands in France. Journal of Environmental Planning and Management [interaktyvus]. 2013 [žiūrèta 2014-04-04]. <http://www.tandfonline. com/doi/abs/10.1080/09640568.2013.7 63772\#preview>.
De Snoo, G.; Herzon, I.; Staats, H.; Burton, R.; Schindler, S.; van Dijk, J.; Lokhors, A. M.; Bullock, J. M.; Lobley, M.; Wrbka, T.; Schwarz, G.; Musters, C. J. M. Toward effective nature conservation on farmland: making farmers matter. Conservation Letters. 2012, 1: 1-7.

Graham, J.; Amos, B.; Plumptre, T. Governance Principles for Protected Areas in the 21st Century. Discussion Paper. Ottawa: Institute on Governance in collaboration with Parks Canada and the Canadian International Development Agency, 2003.

Goslinga, E.; Williams, K. J. H. Connectedness to nature, place attachment and conservation behaviour: testing connectedness theory among farmers. Journal of Environmental Psychology. 2010, 30(3): 298-304.

Eben, M. Public participation during Site Selection for Natura 2000 in Germany: The Bavarian Case. In: S. Stoll Kleemann, M. Welp (Eds.). Stakeholder Dialogues in Natural Resources Management: theoryandpractice. Berlin - Heidelberg: Springer Verlag, 2006, p. 261-274.

ELN-FAB. Functional agrobiodiversity: Nature serving Europe's farmers. Tilburg, the Netherlands: ECNC-European Centre for Nature Conservation, 2012.

Fucks, S.; Stein-Bachinger, K. Nature Conservation in Organic Agriculture a manual for arable organic farming in North- east Germany. Bonn: Federal Germany Nature Conservation Agency, 2008.

Hammer, T. Protected areas and regional development: conflicts and opportunities. Mose, I. (Ed.). Protected Areas and Regional Development in Europe: towards a new model for the 21st century. Aldershot: Ashgate Pub. ltd., 2007a, p. 21-36. 
Herson, I.; Mikk, M. Farmers' perception of biodiversity and their willingness to enhance it through agri - environment schemes: a comparative study from Estonia and Finland. Journal for Nature Conservation. 2007, 15: 10-25.

Hodge, I. Agri-environment policy in an era of lower expenditure: CAP reform and conservation payments. Journal of Environmental Planning and Management. 2013, 56 (2): 254-270.

Höft, A.; Müller, J.; Gerowitt, B. Vegetation indicators for grazing activities on grassland to be implemented in outcome-oriented agri-environmental payment schemes in North-East Germany. Ecological Indicators. 2010, 10: 719-726.

Idle, E. T.; Bines, T. J. Management Planning for Protected Areas. Peterborough: English Nature/Darwin Program initiative, 2005.

International Union for Conservation of Nature (IUCN). Recommendations, Vth IUCN World Parks Congress, Durban, South Africa [interaktyvus]. 8-17 September 2003 [žiūrèta 201402-15]. <http://cmsdata.iucn.org/ downloads/recommendationen.pdf $>$.

Lokhorst, A. M.; Staats, H.; van Dijk, J.; van Dijk, E.; de Snoo, G. R. What's in it for me? Motivational differences between farmers' voluntary and nonsubsidized conservation practices. Applied Psychology-International Review. 2011, 60(3): 337-353.

Mierauskas, P. Gamtosaugos programų igyvendinimo žemès ūkyje socialiniai ekonominiai aspektai. Socialiniu mokslu studijos. 2012a, 4 (4): 1503- 1517.

Mierauskas, P. Saugomy teritoriju politika ir valdymas. Vilnius: Mykolo Romerio universitetas, 2012b.

Mierauskas, P. Biologinei ịvairovei palankaus ūkininkavimo kai kurie socialiniai ekonominiai aspektai. Darnaus vysty- mosi strategija ir praktika. 2011, 1(5): 104-113.

Mierauskas, P. Suinteresuotų asmenų dalyvavimas Lietuvos saugomu teritorijų valdyme. Socialiniu moksly studijos. 2010, 3(7): 125-143.

Mierauskas, P.; Smalskys, V. Saugomų teritorijų sistemų organizavimo principai viešojo valdymo kontekste. Viešoji politika ir administravimas. 2013, 12 (2): 236-247.

Morris, J.; Mills, J.; Crawford, I. M. Promoting farmer uptake of agrienvironment schemes: the Countryside Stewardship Arable Options Scheme. Land Use Policy. 2000, 17 (3): 241-254

Mose, I.; Weixlbaumer, N. A new paradigm for protected areas in Europe? In Mose, I. (Ed.). Protected Areas and Regional Development in Europe: towards a new model for the 21st century. Aldershot: Ashgate Pub. Ltd., 2007, p. 3-19.

Niedzialkowski, K.; Paavola, J.; Jedrzejewska, B. Participation and protected areas governance: the impact of changing influence of local authorities on the conservation of the Bialowieza Primeval forest, Poland. Ecology and Society. [intraktyvus]. 2012, 17 (1): 2 [žiūrèta 2014-02-15]. $<$ http//dx.doi.org/10.575/ES-04461170102>.

Oels, A. Evaluating stakeholder dialogues. S. Stoll-Kleemann, M. Welp (Eds.). Stakeholder Dialogues in Natural Resources Management: theory and practice. Berlin-Heidelberg: Springer Verlag, 2006, p. 118-151.

Osbeck, M.; Schwarz, G.; Morkvėnas, Ž. Dialogue on ecosystem services, payments and outcome based approaches. Stockholm Environmental Institute, 2013.

Peerlings, J.; Polman, N. Farm choice between agri-environmental contracts in the European Union. Journal 
of Environmental Planning and Management. 2009, 52 (5): 593-612.

Raudonytè, J. Ūkinè veikla Lietuvos valstybiniuose parkuose. Annales Geographicae. 2009, 42: 67-76.

Rosenberg, S.; Margerum, R. Landowner motivation for watershed restoration: lessons from five watersheds. Journal of Environmental Planning and Management. 2008, 51 (4): 477-496.

Schwarz, G.; Morkvènas, Ž. Review of outcome based agri-environmental payments and guidelines for the practical implementation of a pilot scheme in Lithuania. Thünen Institute, Baltic Environmental Forum, 2013.

Sherr, S.; McNeely, J. Biodiversity conservation and agricultural sustainability: towards a new paradigm of „ecoagriculture" landscapes. Philosophical Transactions of The Royal Society. 2008, 363: 477-494.

Siebert, R.; Berger, G.; Lorenz, J.; Pfeffer, H. Assessing German farmers' attitudes regarding nature conservation set-aside in regions dominated by arable farming. Journal of Nature Conservation. 2010, 18: 327-337.

Siebert, R.; Toogood, M.; Knierim, A. Factors affecting European farmers' participation in biodiversity policies. Sociologia Ruralis. 2006, 46: 318-340.

Stoll-Kleemann, S.; Welp, M. Towards a more effective and democratic natural resources management. In S. Stoll-Kleemann, M. Welp (Eds.). Stakeholder Dialogues in Natural Resources Management: theory and practice. Berlin-Heidelberg: Springer Verlag, 2006, p. 17-39.

Toogood, M.; Gilbert, K.; Rientjes, S. Farmers and Environment. Assessing the Factors that Effect Farmers' Willingness and Ability to Cooperate with Biodiversity Policies. Tilburg: European Centre for Nature Conservation, 2004.

Welp, M.; de la Vega-Leinert, A. C.; StollKleemann, S.; Jaeger, C. C. Science based stakeholder dialogues: theories and tools. Global Environmental Change. 2006, 16: 170-181.

\title{
EVALUATION OF BIODIVERSITY OF FRIENDLY FARMERS' PARTICIPATION IN THE LITHUANIAN MANAGEMENT OF PROTECTED AREAS
}

\author{
Pranas Mierauskas \\ Mykolas Romeris University, Lihuania
}

Summary. The aim of this article is to overview the motivation for biodiversity of friendly farming and to investigate willingness and possibilities of Lithuanian farmers to participate in the management of protected areas. Lithuanian farmers are participating in different agri-environmental schemes, but participation is not widely used in practice. Agri-environmental schemes are oriented to involve more landowners and reach quantity results focusing of farmers' participation, but not seeking for the biodiversity of oriented quality results and outputs. Friendly farming programmes are not state funded, but they usually get their funds from international conservation projects. Lithuanian landowners 
are not expressing a high degree of willingness to participate in addition in biodiversity conservation programmes, but a certain amount of farmers are already involved in them and there are quite widely spread potential participators. The results of the investigation showed that farmers who have higher understanding of biodiversity would be willing to participate in additional programmes. Biodiversity of friendly farmers could be the potential stakeholders in the management of protected areas. The results of the interview with 80 Lithuanian farmers participating in agro-environmental measures showed that they would be willing to participate in the protected areas management in different ways. One part of them would like to participate in consultation dialogues, others in decision making process or participating in joint protected areas' administrations councils, but some of them stated that they would not be able to participate. The farmers expressed opinions that participation in any form would allow to avoid conflicts between landowners and protected area's administration staff.

Keywords: protected areas management, stakeholders, biodiversity friendly farming, farmers, agro-environmental measures.

Pranas Mierauskas, Mykolo Romerio universiteto Politikos ir vadybos fakulteto Viešojo administravimo instituto Aplinkos valdymo centro docentas. Mokslinių tyrimų kryptys: saugomų teritorijų valdymas, ekosistemų valdymas, gamtosaugos politikos veiksmingumas ir efektyvumas, ekologinis vertinimas, aplinkosaugos planavimas.

Pranas Mierauskas, Mykolas Romeris University, Faculty of Politics and Management, Institute of Public Administration, Center for Environmental Management, Associate Professor. Research Interests: Protected Areas Governance, Ecosystem Management, Efficiency and Effectiveness of Nature Conservation Policy, Ecological Evaluation, Environmental Planning. 